\title{
Correction to: Growth in the docks: ports, metabolic flows and socio-environmental impacts
}

\section{Borja Nogué-Algueró ${ }^{1}$ [D}

Published online: 25 May 2021

๑) Springer Japan KK, part of Springer Nature 2021
Publisher's Note Springer Nature remains neutral with regard to jurisdictional claims in published maps and institutional affiliations.

In the original publication of the article, the acknowledgment section was published incorrectly. The correct acknowledgment is provided below.

Acknowledgements The author is financially supported by the Spanish Ministry of Science and Innovation through the FPU fellowship program (FPU17/05908). Thanks to Daniel Macmillen Voskoboynik, David Ravensbergen and Benjamin Irvine for their valuable comments and suggestions on earlier versions of this article. Special thanks to the editors of the Special Issue and the two anonymous reviewers for providing insightful comments. Any error remains on the author.

The original article can be found online at https://doi.org/10.1007/ s11625-019-00764-y.

Borja Nogué-Algueró

borja.nogue@mailbox.org; borja.nogue@uab.cat

1 Institute of Environmental Science and Technology (ICTA),

Universitat Autonòma de Barcelona, 08193 Bellaterra,

Barcelona, Spain 